$$
\begin{gathered}
\text { 양측 이개 상부에 발생한 거대 켈로이드의 } \\
\text { 외과적 절제 후 방사선 치료 } 1 \text { 예 } \\
\text { 인제대학교 의과대학 부산백병원 이비인후- 두경부외과학교실 } \\
\text { 김 상 렬 }
\end{gathered}
$$

\title{
A Case of Surgical Excision with Radiation Therapy on the Both Auricular Huge Keloids
}

\author{
Sang Ryul Kim, MD \\ Department of Otolaryngology-Head and Neck Surgery, College of Medicine, Inje University, \\ Busan Paik Hospital, Busan, Korea
}

\section{-ABSTRACT -}

A keloid is defined as uncontrolled benign proliferation of dense fibrous scar tissue. Various techniques have been proposed to treat keloid, and now combination techniques such as surgery with radiation therapy gain ground because of frequent recurrences. We report a case of a 22 -year-old male who was treated with radiotherapy after surgical excision on the both auricular huge keloids. (J Clinical Otolaryngol 2005;16:160-162)

KEY WORDS : Keloid · Radiotherapy.

\section{서 론}

켈로이드는 피부 손상 또는 자연적으로 발생하는 진피 섬유조직의 과성장을 특징으로 하는 양성 결절성 종괴 로서, 높은 재발률을 특징으로 한다. ${ }^{1)}$ 켈로이드는 10 30 세의 흑인에서 가장 흔하게 발생하여 $16 \%$ 이상의 유 병률을 나타내는 것으로 보고되고 있으나, ${ }^{2)}$ 국내에서의 유병률은 보고된 것이 없다. 이과 영역에서는 주로 귀걸 이를 하기 위해 귀를 뜷은 후 발생하거나 화상, 수술적

논문접수일 : 2005년 4월 3일 심사완료일 : 2005년 5월 11일

교신저자 : 김상렬, 614- 735 부산광역시 진구 개금1동 633- 165 인제대학교 의과대학 부산백병원 이비인후두경부외과학교실

전화 :(051) 890- 6376,6375. 전송 : (051) 892- 3831

E- mail : iment1@yahoo.co.kr
치료, 감염, 외상 등에 의해서 이수에 발생하는 경우가 가장 흔하며 이륜 후방에 발생한 경우도 보고되고 있 다. ${ }^{3)}$ 치료는 외과적 절제술, 스테로이드의 병변내 주입, 압박요법, 냉동치료, 인터페론 주입, 실리콘겔 판금, 방사 선 치료 등이 단독 또는 병합되어 이용되고 있다. ${ }^{4) 5)}$

저자들은 과거 절제의 경험이 있는 양측 이개 상부의 거대 켈로이드를 외과적 절제 후 방사선 치료와 병합하 여 좋은 결과를 보인 예를 경험하였기에 문헌 고찰과 함께 보고하고자 한다.

\section{증 례}

22세 남자 환자가 양측 이개 상부에 발생한 거대 종괴 를 주소로 본원 이비인후과 외래에 방문하였다. 과거력 상 약 10년 전 좌상을 당한 후 양측 이개 상부에 종괴가 발생하였고 3년 전 개인 의원에서 외과적 절제술을 시행 

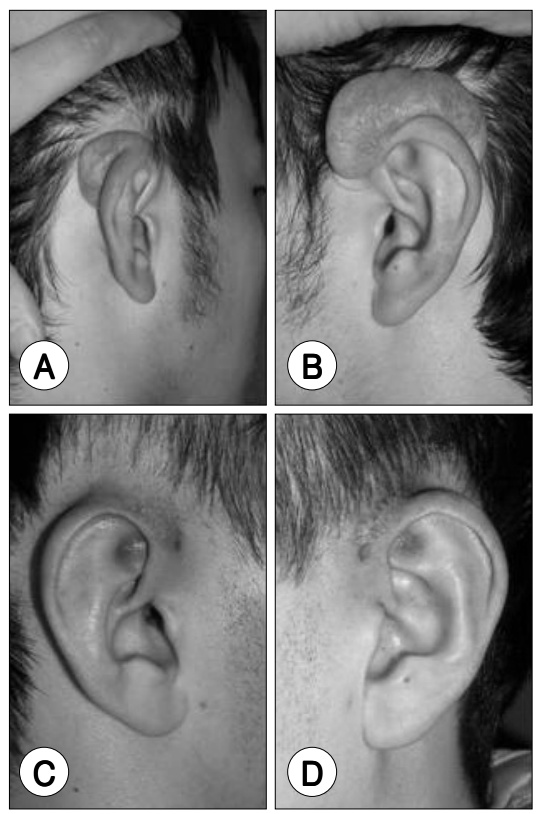

Fig. 1. A, B : Preoperative view of cylindric mass on superior area of auricle C, D : Postoperative view.

받은 병력이 있었다. 가족력상 특이 사항은 없었다. 이학 적 검사상 우측 $4 \times 3 \times 1.5 \mathrm{~cm}$, 좌측 $6 \times 3 \times 2 \mathrm{~cm}$ 크기 의 무통성 종괴가 원통형의 결절 형태로 넓은 기저부를 통해 이개 상부에 고정되어 있었다(Fig. $1 \mathrm{~A}$ and $\mathrm{B}$ ).

우선 환자는 외래 방문을 통해 매주 1회, 6 주에 걸쳐 병변내 스테로이드(triamcinolone, $5 \mathrm{mg} / \mathrm{each}$ side) 주 입을 시행 받았으며, 그 결과 우측은 $3.3 \times 2.2 \times 1.0 \mathrm{~cm}$, 좌측은 $4.6 \times 3.0 \times 1.2 \mathrm{~cm}$ 크기로 줄었다.

마지막 병변내 스테로이드(triamcinolone, $10 \mathrm{mg}$ ) 주 입 2주 후, 저자들은 전신마취하에 변연내 절제술(intramarginal excision) 을 통해 종괴를 제거하였고 6- 0 나일론 봉합사로 피하조직을 포함하지 않고 진피 부위만 을 봉합하였다. 병리조직검사상 성긴 점액양 기질 내에 섬유모 세포의 분화를 보이는 켈로이드로 확진되었다 (Fig. 2). 환자는 술 후 7일째 발사하기 전까지 수술부 위의 압박치료를 받았으며 술 후 2일째부터 4일간 총 1200 cGy (300 cGy/day)의 방사선 치료를 시행받았다. 병변 주위 $1 \mathrm{~cm}$ 이외의 부분은 납판으로 차폐하여 병변 부위 $1 \mathrm{~cm}$ 범위까지 방사선 치료 범위에 포함시켰다. 환자의 창상부위 유합은 잘 되었고, 귀 모양의 변형이

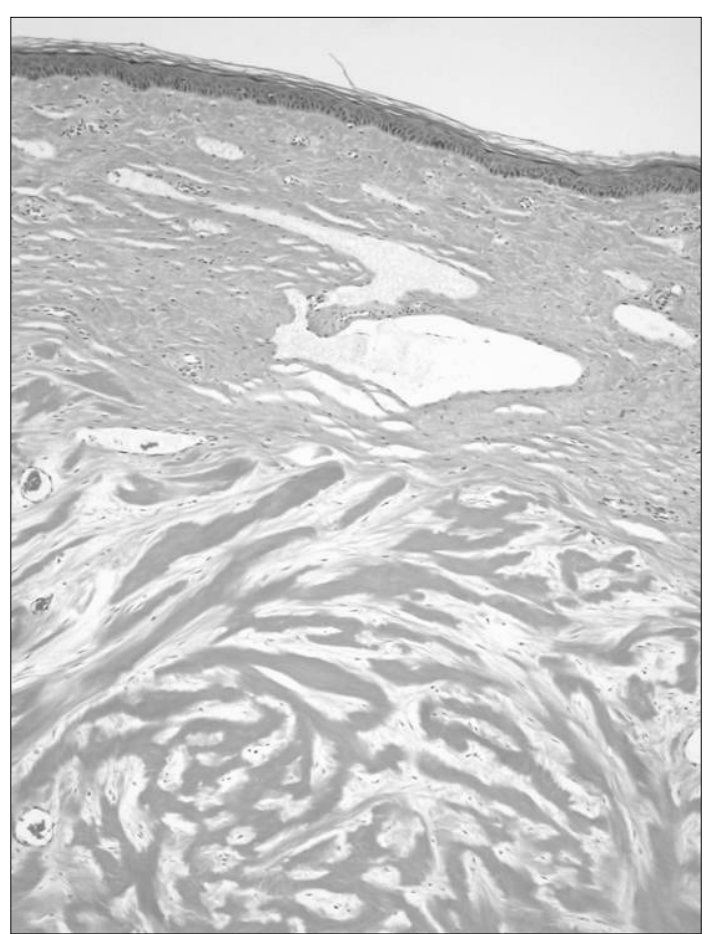

Fig. 2. Higher magnification shows loosely packed collagen bundle with overabundant extracellular matrix $(\mathrm{H}$ $\& \mathrm{E}, \times 100)$.

나 피부의 과색소 침착, 동통, 소양증 등은 보이지 않았 으며 술 후 9 개월이 지난 현재 재발 소견은 보이고 있지 않다(Fig. 1C and D).

\section{고 찰}

켈로이드는 과도한 교원섬유의 침착을 가지는 섬유질 의 종양으로서 대부분 외상에 의해 발생하나, 드물게 특 정 증후군 또는 가족력이나 인종과 관련되어 주로 전흉 부에 저절로 발생하기도 한다. ${ }^{46)}$ 대개 흉골부, 어깨, 상 측 배부에 발생하며 이비인후과 영역에서는 귀걸이를 하 기 위해 귀를 뜷은 후 이수 부위에 생기는 경우가 많다. 지위 상징으로 피부 장식을 하는 문화적 특성으로 인해 아프리카 종족에게 가장 흔히 나타나며, 흑인과 스페인 사람에게서는 $16 \%$ 이상의 유병률을 보이고 있다. 가장 많은 유병률을 보이는 연령은 20 30대로 알려져 있 다. ${ }^{2)}$ 흔한 임상 증상으로 소양감 또는 통증이 있으며, 
피부협착으로 인해 해부학적으로 기능부전을 야기하기 도 한다. ${ }^{7) 8)}$

감별해야 할 질환으로 비후성 반흔이 있으며, 이는 병 리조직학적 차이로 인해 구별되어진다. 병리조직학적으 로 켈로이드와 비후성 반흔은 모두 교원섬유조직의 과 증식을 보이고 있으나, ${ }^{6)}$ 켈로이드는 선회형의 결절 양상 을 나타내며 피부 손상 가장자리를 넘어 자라는데 반해 비후성 반흔은 피부표면과 평행하게 편평해지는 양상을 보이며 피부손상부위를 넘어 자라지는 않는다. ${ }^{9)}$ 또한 켈 로이드에서는 비후성 반흔보다 근섬유모세포가 적은 비 율로 섬유모세포에서 관찰된다. 켈로이드에서 전자 현미 경 소견상 무작위 배열의 교원질이 관찰되며, ${ }^{4)}$ 분자생물 학적으로 정상 조직에서의 섬유모세포와 비교할 때 켈 로이드에서의 섬유모세포에서는 T GF- $\beta 1$, T GF- $\beta 2$ 가 증가되어 있다. ${ }^{10)}$ 따라서 최근 TGF- $\beta 2$ 항체를 통한 켈로이드의 치료에 대해 연구가 이루어지고 있다. ${ }^{11)}$

치료로는 외과적 절제술, 스테로이드의 병변내 주입, 압박요법, 냉동치료, 인터페론 주입, 실리콘겔 판금, 방 사선 조사 등의 여러 가지 방법이 있으나 높은 재발율로 인해 여러 병합요법이 시도되고 있다. 외과적 절제술시 높은 재발률로 인해 대부분 다른 치료와 병합되어 사용 되고 있으며, 재발률을 낮추기 위한 방법으로 피부 긴장 도의 증가를 막기 위해 피부이식이나 진피조직만을 봉 합하는 방법들이 사용되고 있다. 특히 켈로이드의 절제 시 섬유모 세포의 활성이 높아지는 것을 방지하기 위해 변연내 절제술을 이용하여 재발을 낮출 수 있다는 보고 가 있다. ${ }^{4)}$ Sclafani 등 ${ }^{12)}$ 은 전향적인 조사를 통해 스테 로이드 병변내 주입과 방사선 치료를 비교한 결과 방사 선 치료가 더욱 효과가 우수하다는 것을 발표하였으며, 1990 년 Lo 등 ${ }^{12)}$ 이 174 개의 켈로이드를 외과적 절제술 후 방사선 치료를 병합하여 $86 \%$ 의 치료 성공을 처음으 로 보고한 후 방사선 치료에 대한 여러 프로토콜이 제시 되었으며, Ion 등 ${ }^{13)}$ 은 외과적 절제술 후 섬유모세포가 분화하기 전인 48시간 내 방사선 치료를 병합하는 것이 가장 좋은 치료 효과를 나타내며, 외과적 절제술 후 24 48시간 내 $10 \mathrm{~Gy}$ 의 일회 방사선 치료를 프로토콜로 제 시하였다. 방사선치료의 합병증으로 창상부위의 불유합, 귀모양의 변형, 피부의 과색소 침착, 동통, 소양증 등이 있으나 아주 드물게 나타날 수 있다.
하지만 켈로이드 치료에 있어 장기적 추적 관찰이 이 루어진 연구가 없었으며 재발의 평가가 명확히 규정되 지 않았다는 점에서 더 많은 연구가 필요하리라 사료된다.

\section{결 론}

켈로이드는 높은 재발률을 특징으로 하며 두경부 영역 에서는 주로 이수에 생기는 경우가 가장 흔하다. 저자들 은 최근 양측 이개 상부에 발생한 거대 켈로이드를 외 과적 절제술 후 방사선 치료를 병합하여 만족할만한 효 과를 거둔 1 예를 치험하여 보고하는 바이다.

중심 단어 : 켈로이드. 방사선 치료.

\section{REFERENCES}

1) Young HS, August PJ. Pulsed-dye laser treatment for keloid scars. Br J Dermatol 2003; 149:22.

2) Murray JC, Pollack SV, Pinnell SR. Keloids: A review. J Am Acad Dermatol 1981;4:461-70.

3) Har-Shai Y, Amar M, Sabo E. Intralesional cryotherapy for enhancing the involution of hypertrophic scars and keloids. Plast Reconstr Surg 2003;111:1841-52.

4) Murray JC. Scars and keloids. Dermatol Clin 1993;11: 697-708.

5) English RS, Shenefelt PD. Keloids and hypertrophic scars. Dermatol Surg 1999;25:631-8.

6) Sherris DA, Larrabee WB, Murakami GS. Management of scar contractures, hypertrophic scar, and keloids. Otolaryngol Clin North Am 1995;28:1057-67.

7) Urioste SS, Arndt KA, Dover JS. Keloids and hypertrophic scars: Review and treatment strategies. Semin Cutan Med Surg 1999;18:159-71.

8) Haverstock BD. Hypertrophic scars and keloids. Clin Pediatr Med Surg 2001;18:147-59.

9) Barzilai A, Lyakhovitsky A, Horowitz A, Trau H. Keloidlike Scleroderma. Am J Dermatopathol 2003;25:327-30.

10) Liu W, Wang DR, Cao YL. TGF-beta: A fibrotic factor in wound scarring and a potential target for anti-scarring gene therapy. Curr Gene Ther 2004;4:123-36.

11) Smith P, Mosiello G, Deluca L, Ko F, Maggi S, Robson MC. TGF-beta2 activates proliferative scar fibroblasts. J Surg Res 1999;82:319-23.

12) Ogawa R, Mitsuhashi K, Hyakusoku H, Miyashita T. Postoperative electron-beam irradiation therapy for keloids and hypertrophic scar: Retrospective study of 147cases followed for more than 18 months. Plast Reconstr Surg 2003;111: 547-53.

13) Ion LE, Ragoowantsi R, Moss ALH. Dressing to facilitate early radiotherapy after excision of keloid. British J Plast Surg 1999; 52:322-30. 